\title{
Spatial Policy of Selected Communes in Vicinity of Warsaw in Scope of Land Consolidation Areas and Secondary Land Property Divisions
}

\begin{abstract}
The aim of this article was to analyze planning documents - a study of the preconditions and guidelines of spatial development of communes and local spatial development plans - in the context of regulations related to the division into building plots. The analysis was carried out on the examples of selected communes near Warsaw, and planning documents from the years of 1995-2016 were evaluated.

This analysis has shown that the issue of land consolidation and the secondary divisions of plots is omitted in studies of the preconditions and guidelines of spatial development. Only exceptionally adjustments are made to the existing parcel divisions in the local plans. Most of them are adapted even when they are not suitable for new functions. It is up to the owners of the properties to make their way of sharing, including internal communication. The rules for the division of land into building plots are mostly in the form of postulates. The minimum plot area was established by a single planning regulation.

The minimization or lack of planning regulations in this subject may lead to defective spatial structures, costly in the eventual future process of improving utility standards. There are - on analyzed areas - not only individual plots developed in this way but even entire quarters, cut by a grid of long and narrow streets, serving plots that are difficult to be properly built.
\end{abstract}

Keywords: spatial policy, land consolidation and secondary divisions of plots

Received: 12 December 2017; accepted: 6 February 2018

\footnotetext{
* Warsaw University of Technology, The Faculty of Geodesy and Cartography, Warsaw, Poland
} 


\section{Introduction}

The basis of the execution of a functional building is - literally and metaphorically - the plot on which it will be constructed. The relevant surface area of a building plot, its proper shape and proportions, and its access to a road (internal or public) with parameters providing for adequate service in the scope of transport and engineering networks permits the design and construction of an object meeting all standards and useful requirements. A lack or deficiency of any or all of the above factors will reduce the quality of use of the buildings. It can also negatively affect the spatial structure of an area - through the appearance of different or even substandard forms with shapes determined by defective parcellation divisions. The Property Management Act [1] entitles commune authorities to interfere with the existing parcellation structures for the purpose of their adjustment to their new function. The condition is the designation of the area in the local spatial development plan, together with the determination of detailed conditions of land consolidation and property division.

The objective of this article is to analyze whether and to what degree commune authorities use the aforementioned statutory possibilities, providing the basis for the creation of spatial order in areas intended for single-family housing development. For this purpose, nine communes were selected (eight urban and one urban-rural commune): Józefów, Kobyłka, Legionowo, Marki, Otwock, Sulejówek, Wołomin, Ząbki and Zielonka. The analysis covered the binding planning documents: namely, studies of preconditions and guidelines of spatial development (hereinafter referred to as studies) as well as selected local spatial development plans (hereinafter referred to as local plans) passed in the aforementioned communes during the years of 1995-2016 based on the act on spatial planning and development [2] and the former act on spatial development [3] (documents passed under the act have remained in legal force). The acts differed in the scope of the required planning regulations, among other things.

\section{Land Consolidation Areas and Secondary Land Property Divisions in Study of Preconditions and Guidelines of Spatial Development}

Figure 1 presents the activity of the analyzed communes in the scope of determining their spatial policy. Out of the nine communes, two (Legionowo and Marki) did not pass the study under the former 1994 act. After the statutory changes, all of the self-governments prepared and passed the studies or their amendments. 

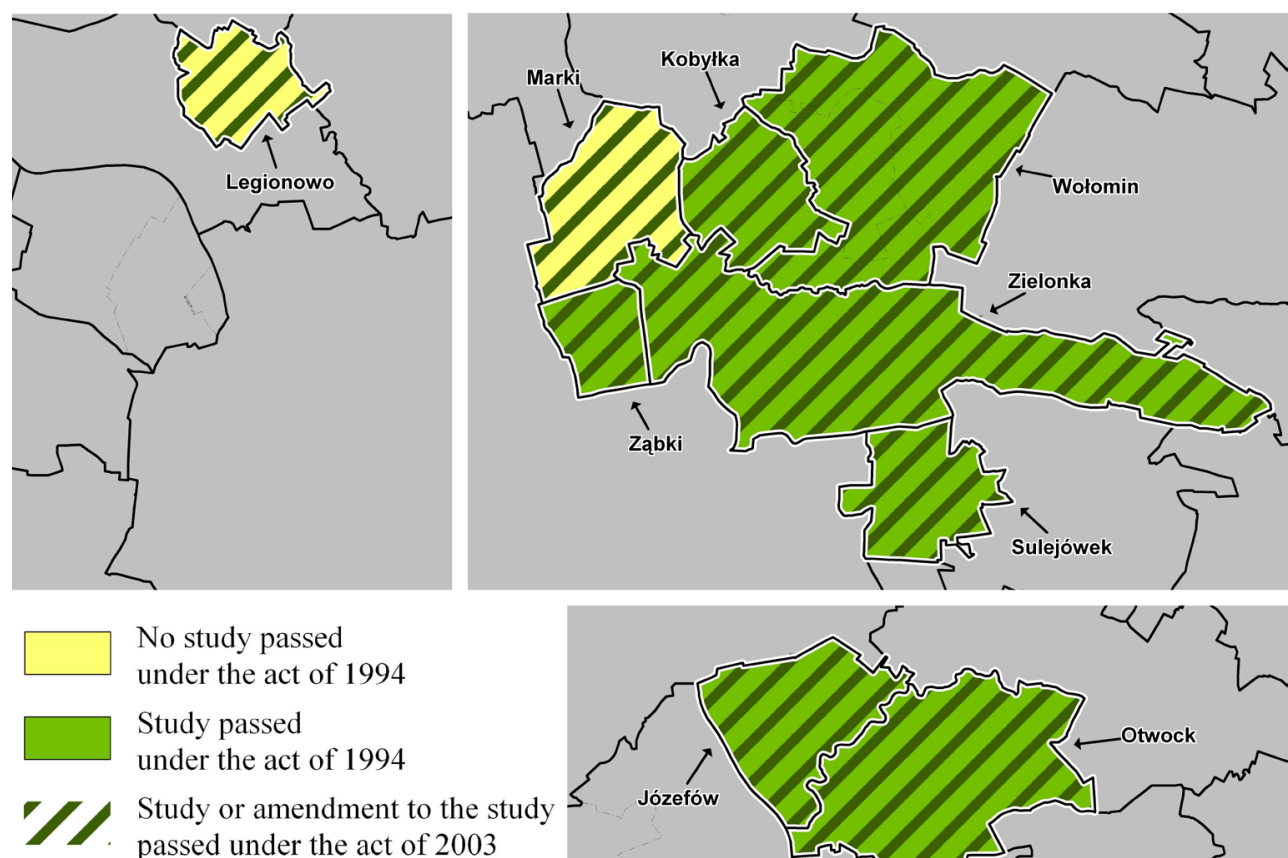

No study passed under the act of 1994

Study passed under the act of 1994

Study or amendment to the study passed under the act of 2003

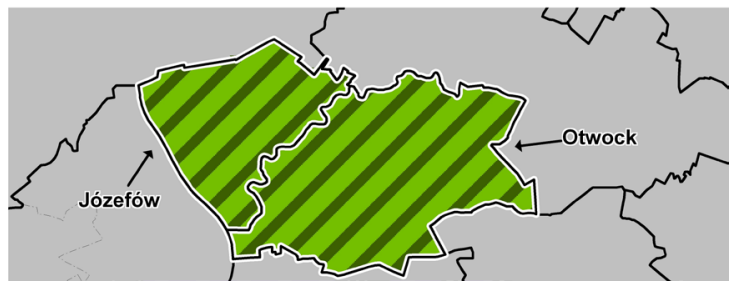

Fig. 1. Period of passing of studies in analyzed communes

Source: own elaboration based on selected official journals of Warsaw Voivodeship (1995-1998) [4] and official journals of Mazowieckie Voivodeship (1999-2016) [5]

The analysis of the aforementioned currently binding documents showed that the issue of land consolidations and secondary divisions is marginalized or even ignored. Only in one commune (Otwock [6, p. 67]) were such areas indicated. In the studies of three communes, the issue of consolidation areas was omitted and two others included information on the lack of their designation - with no justification ("No areas designated for the obligatory preparation of the local spatial development plan due to the need of performance of land consolidation and property division into building plots currently occur in the city." [7, p. 28]) ("Areas requiring the application of the legal obligation of land consolidation and property division are not designated in the study; therefore, no such areas are delineated in the study drawing." [8, p. 85]), and a further three with an identical brief justification ("The existing ownership and spatial structure of land permits the development of the city and its transformations without imposing the obligatory performance of land consolidations and property divisions" $[9$, p. $70 ; 10$, p. $75 ; 11$, p. 94]. In spite of the lack of the designation of areas for land consolidation and property divisions in the aforementioned studies, three of them mention the possibility of implementing the said process, leaving the decision to the land property owners. The provisions read 
similar to each other ("Nonetheless, in individual cases of single investors, should such a need occur resulting from the type of undertaking, land consolidation and property division can always occur based on the application submitted by the interested parties pursuant to the Act of August 21, 1997, on land property management." [9, p. 70]) ("Nonetheless, in individual cases, should such a need occur, land consolidation and property division can occur based on the application submitted by the interested parties pursuant to the property management act." [10, p. 75]) ("Nonetheless, in individual cases, should such a need occur, land consolidation and property division can occur based on the application submitted by the interested parties pursuant to the 1997 act on property management." [11, p. 94]). One of the studies points to the necessity of stipulating the regulations in local plans of the planning for parcels intended for building development: "However, in the prepared local plans and their amendments for the areas in which the current division (formerly agricultural) is inappropriate for the allocation of the parcels for new residential or residential and service investments, relevant regulations should be stipulated for individual land consolidations and secondary property divisions." [8, p. 85].

\section{Land Consolidation Areas and Secondary Land Property Divisions in Local Spatial Development Plans}

The said communes differ in the degree of cover with binding local spatial development plans. Figure 2 presents their planning areas by documents prepared both under the former and currently binding acts. It should be emphasized, however, that the percentage values do not consider the differentiation of the communes in terms of surface area or spatial development. Two of the communes are entirely covered by local plans (Legionowo and Ząbki), and a third is practically so (namely, Zielonka) after deducting the closed areas (in terms of surface area, this is "only" $18 \%$ ). A further two communes (Marki and Kobyłka) are characterized by a high degree of cover with planning areas ( $89 \%$ and $77 \%$, respectively). More than half of the area of the commune is covered by the plans in Sulejówek (56\%), and approximately one third in Otwock (32\%) and Józefów (31\%) are covered. The smallest surface area covered by local plans (amounting to several percent) occurs in Wołomin $(8 \%)$, concerning both the city itself and a rural part of the commune.

The contribution of local plans prepared in accordance with binding statutory regulations is also variable. The largest areas of a commune covered by such plans occur in Sulejówek (50\%) and Legionowo (41\%). Kobyłka is covered by such plans at $20 \%$, Ząbki $-13 \%$, and Józefów $-10 \%$, Wołomin $-7 \%$, Otwock $-2 \%$, and Marki $-1 \%$. In the above classification, Zielonka takes fourth place (15\%); although, after deducting closed areas, the remaining area is covered by the said plans to the highest degree (at $83 \%$ ). 
The above contribution is important due to the variable statutory requirements. The scope of the obligatory determinations was considerably smaller before 2003 than currently, and the scope of the regulations concerning the rules of building development and land management was determined individually by self-governments. This also concerned the rules and conditions of the division of land into building plots that were originally designated in local plans "depending on needs" ([3] art. 10, par. 1, point 7). Currently, the "boundaries of areas requiring land consolidations and property divisions" ([2] art. 15, par. 3, point 1) are designated optionally, and "detailed rules and conditions of consolidation and division of land property covered by the local plan" ([2] art. 15, par. 2, point 8) - obligatorily. They should include the "specification of the parameters of the plots obtained as a result of property consolidation and division, particularly the minimum and maximum widths of the fronts of the plots, their surface areas, and the specifications of the angles of location of the plot boundaries as related to the road belt" ([12] §4, point 8).

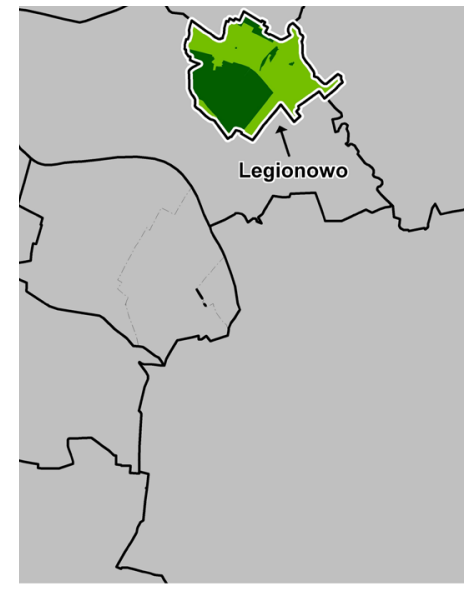

No local plan passed

Local plans passed under the act of 1994

Local plans passed under the act of 2003
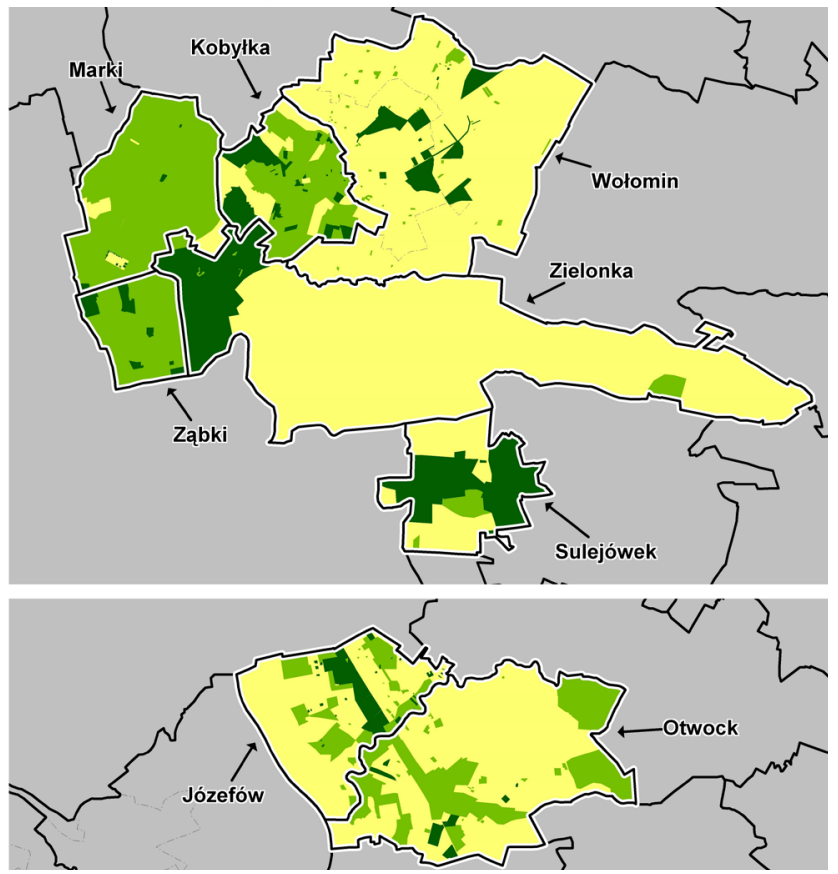

Fig. 2. Planning situation in analyzed communes

Source: own elaboration based on selected official journals of Warsaw Voivodeship (1995-1998) [4] and official journals of Mazowieckie Voivodeship (1999-2016) [5]

For the purpose of analyzing whether and to what degree the above specifications were included in the binding local spatial development plans, two passed 
plans from each of the analysed communes were selected: one prepared under the former Act, and one passed under the currently binding one (Tab. 1). The selection criteria concerned the occurrence in planning areas of land properties intended for single-family housing development, entirely or partially undeveloped, with the parcellation structure requiring (at least partially) the implementation of land consolidation and secondary property division into building plots (according to the authors).

Table 1. Specifications concerning building plots in example binding local spatial development plans

\begin{tabular}{|c|c|c|c|c|c|c|c|}
\hline \multirow{3}{*}{ Commune } & \multicolumn{2}{|c|}{ Commune council resolution } & \multicolumn{5}{|c|}{ Specifications concerning building plots } \\
\hline & \multirow{2}{*}{ Year } & \multirow{2}{*}{ Resolution No. } & \multicolumn{2}{|c|}{ Area } & \multicolumn{2}{|c|}{ Front width } & \multirow{2}{*}{$\begin{array}{l}\text { Location } \\
\text { angle }\end{array}$} \\
\hline & & & Min. & Max. & Min. & Max. & \\
\hline \multirow{2}{*}{ Józefów } & 2005 & 426/IV/2005 & + & - & - & - & - \\
\hline & 2016 & 210/VII/2016 & + & - & + & - & + \\
\hline \multirow{2}{*}{ Kobyłka } & 1999 & VIII/63/99 & + & - & - & - & - \\
\hline & 2008 & XXVI/283/08 & + & - & + & - & + \\
\hline \multirow{2}{*}{ Legionowo } & 2001 & XLI/492/2001 & + & - & - & - & - \\
\hline & 2009 & XXIII/291/2008 & + & - & - & - & - \\
\hline \multirow{2}{*}{ Marki } & 1999 & XIII/86/99 & + & - & - & - & - \\
\hline & 2016 & XXVIII/212/2016 & + & - & + & - & + \\
\hline \multirow{2}{*}{ Otwock } & 2005 & XXXII/272/05 & + & - & - & - & - \\
\hline & 2006 & XLIX/391/06 & + & - & - & - & - \\
\hline \multirow{2}{*}{ Sulejówek } & 2002 & 443/L/02 & - & - & - & - & - \\
\hline & 2008 & 150/XXV/08 & + & - & - & - & - \\
\hline \multirow{2}{*}{ Wołomin } & 2000 & XI-297/99 & + & - & - & - & - \\
\hline & 2012 & XIX-83/2012 & + & - & + & - & + \\
\hline \multirow{2}{*}{ Ząbki } & 2003 & 90/XVIII/03 & + & - & - & - & - \\
\hline & 2013 & LI/459/2013 & + & - & + & - & + \\
\hline \multirow[b]{2}{*}{ Zielonka } & 2002 & LIII/287/02 & + & - & - & - & - \\
\hline & $\begin{array}{l}2010 \\
2014\end{array}$ & $\begin{array}{c}\text { XLIV/420/10 / } \\
\text { XLIX/522/14 }\end{array}$ & + & - & + & - & + \\
\hline
\end{tabular}

Colors: dark green - local plans passed under the 2003 act; light green - local plans passed under the 1994 act

Source: own elaboration based on selected official journals of Warsaw Voivodeship (1995-1998) [4] and official journals of Mazowieckie Voivodeship (1999-2016) [5]

In the majority of the analyzed plans, the existing parcellation structure remained unchanged. The proposed divisions of land designated by lines delineat- 
ing building plots presented in the drawings of the plans have the character of postulates - with no references in the text of a plan that would ensure their execution. The way of dividing them into building plots, and for some land, the provision of transport service was left for the decisions of the property owners. No access roads to parts of the parcels were designed; only the required parameters of the roads were determined: mainly, width and (more seldomly) the maximum length in the case of dead ends as well as the ways that they end. Also, no necessity of the creation of crosswise junctions permitting alternative road access to the parcels was stipulated. The above lack of building quarters delineated by the designed transport system can negatively affect the designation of parcels with shapes appropriate for building development and with proper road access.

A commonly occurring specification (with the exception of one plan) was that of the minimum area of building plots. It permits the designation of plots with an area corresponding with their purpose and intensity, eliminating excessive building development density. In single-family housing areas, this was additionally variable depending on the form of the building development: for detached, twin, or semi-detached housing. Such variability resulting from common admittance of all of the above forms within the same functional areas, as well as the lack of specification of maximum values (in any of the analyzed plans) can lead to a lack of certain unification of the parcellation structures in particular quarters. They may include plots with areas even several times smaller or larger than those of the remaining ones, and the executed buildings will differ from the surrounding building development. This results from the relative character of the urban planning indices (intensity and area of building development) referred to the area of building plots. The above regulations were the only ones concerning the rules of division into building plots in local plans prepared under the former act. The majority of the plans passed under the currently binding act also include regulations concerning the minimum front width and location angle of the plot in relation to the access road. Only one plan refers to the proportions of plots (specifying the ratio of their widths to depths), and none refer to the ways of the arrangement (shorter side) of plots towards the access road. The above regulations are not less important than the area of building development. Plots with the same area can have different proportions; e.g., approximate to a square, but also an elongated rectangle, in extreme cases with a multiple ratio of sides, forcing the execution of a building with a narrow front (even of only several meters). Another issue is the non-perpendicular arrangement of plots towards the access road, resulting in the oblique orientation of buildings towards the road (usually with the shorter side), developing a "ragged" frontage. The scenarios presented above justify a planning interference in areas with defective parcellation divisions.

Corrections of the existing divisions were undertaken in 3 out of the 18 analyzed plans. The first of them is the local spatial development plan of the city of Józefów (the "Kolonia Błota" area). Areas of "common activities in the scope 
of consolidation and secondary division of property" were designated there $(\$ 10$, par. 1 [13]) requiring the implementation of the land consolidation process: either in accordance with the statutory provisions or as an individual arrangement of property owners. The above requirements, however, only concern three fragments of the planning area, including several registered plots each. In two of the cases, this concerns the situation of the lack of transport services of part of them, and one of the said areas covers three elongated plots with a width of approximately a dozen meters, making their individual building development impossible. After the consolidation and secondary division, this will be possible, but the created plots will be oriented with their longer sides towards the roads, which will largely reduce their privacy (Fig. 3). The remaining regulations concerning the divisions were limited to adequate transport service and the minimum area of building plots as well as - in the case of longer sides of plots running along the road - reducing their lengths to a double value of the lengths of the shorter sides. The lines of the proposed divisions into the building plots were also indicated. They only have the character of the guidelines.

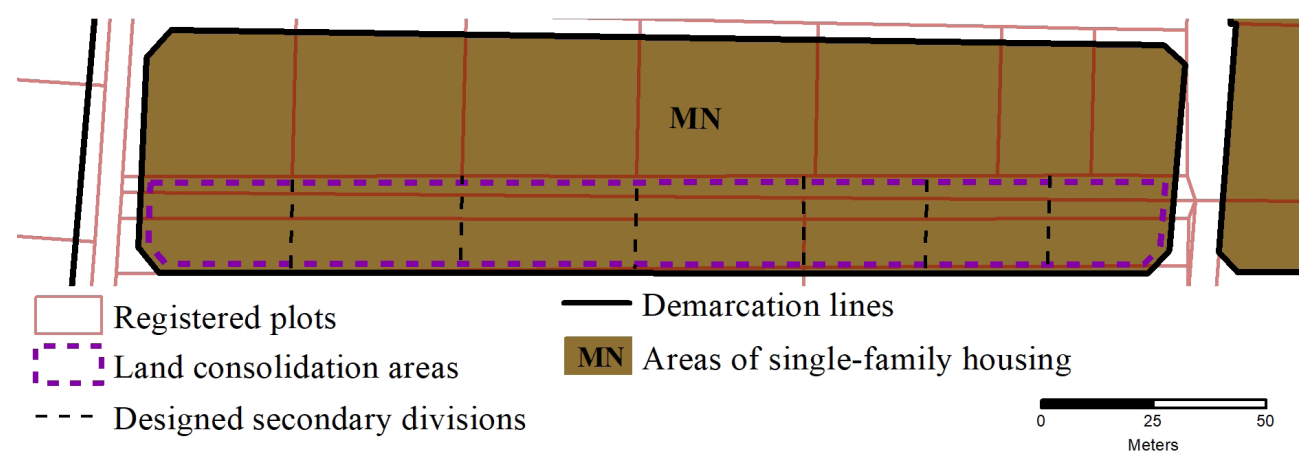

Fig. 3. Example area designated for consolidation and secondary division into building plots

Source: own elaboration based on local plan drawing [13]

Another document stipulating the requirement of land consolidation and secondary division is the local spatial development plan of the city of Sulejówek for a complex of plots with registry numbers 56/1,56/2, 56/3, 56/5, 56/6, 57/1, 57/2, $57 / 3$, and $57 / 4$ in area 63 , within their ownership. The requirement of consolidations and secondary divisions, however, does not refer to a particular area (the entire planning area or its part), but it has the form of a general regulation: "Plots or complexes of building plots with shape, size, ownership structure, accessibility of public roads and infrastructure, land relief, and cover making their use and development in accordance with the provisions of the plan difficult should be consolidated and subject to secondary division." (\$25 [14]). Except for the 
above provision, no planning regulations were included concerning the rules of division into plots, even those concerning their minimum areas. The planning area - with a width of approximately $100 \mathrm{~m}$ and a length of approximately $900 \mathrm{~m}$ - is located between two public roads: to the south and north. Only two cross junctions were designated there (on the east-west axis). The original parcellation division (from the period of passing the plan) and the current one is presented in Figure 4. On the north-south axis, an internal road was designated with a length of approximately $1 \mathrm{~km}$ running in the southern part along the western boundary of the area and then in its middle. The parcels designated around it as well as their arrangement and parameters raise no reservations. Along a section of approximately $700 \mathrm{~m}$, however, no cross junctions occurs, and the continuous both-sided sequence of approximately twenty plots makes the impression of monotony.

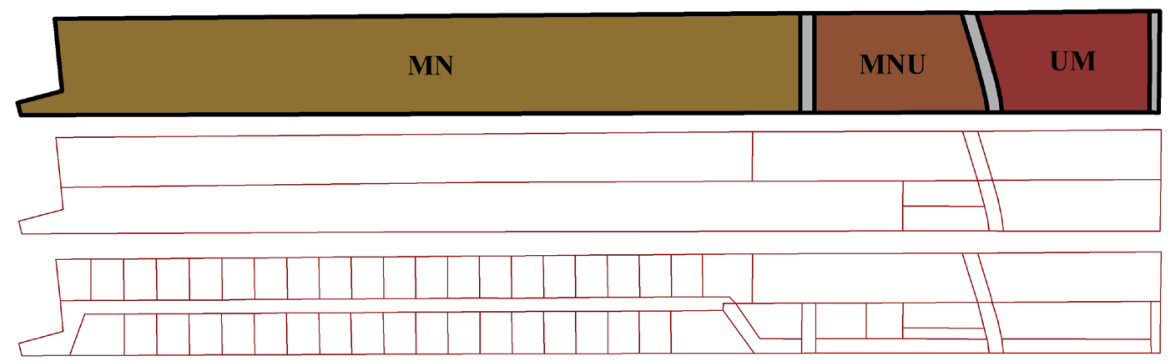

MN Single-family residential areas

MNU Single-family residential and service areas

uM Service and single-family residential areas

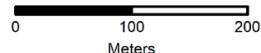

Fig. 4. Plan drawing (top), original parcellation structure (middle), and current parcellation structure (bottom)

Source: own elaboration based on local plan drawing [14] and website of town of Sulejówek (www.sulejowek.pl)

The third plan addressing the issue of correcting the existing parcellation structure is the local spatial development plan of a part of the city of Sulejówek. The plan drawing shows areas requiring reparcellation (one of them is presented in Figure 5), classifying the above marking as a planning designation (\$7 par. 2 point 16 [15]). The rules of the division into building plots, however, were limited to their minimum areas, and in terms of transport service - to the designation of zones of designed driveways to building complexes as well as the minimum width of the access roads. This can prove insufficient in preventing the development of defective parcellation structures, generating high costs in the potential future process of improving usability standards. 

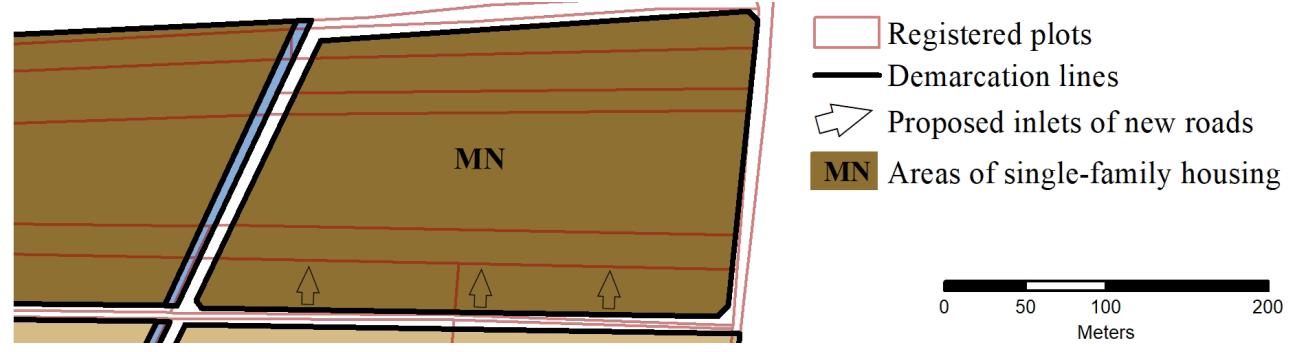

Fig. 5. Example area requiring reparcellation.

Source: own elaboration based on local plan drawing [15]

\section{Conclusion}

All of the above suggests that the spatial policy concerning parcellation structures generally involves the transfer of the decision onto property owners. This way, communes avoid procedures unpopular among residents, generating potential conflicts and costs. The lack of planning interference in the obsolete divisions, however, will result in the development of substandard urban planning systems, the correction of which will be impossible or much more expensive after their development.

\section{References}

[1] Ustawa z dnia 21 sierpnia 1997 r. o gospodarce nieruchomościami [Act of 21 August 1997 on real estate management]. Consolidated text: Dz.U. 2016, poz. 2147, with amendments.

[2] Ustawa z dnia 27 marca 2003 r. o planowaniu $i$ zagospodarowaniu przestrzennym [Act of 27 March 2003 on spatial planning and development]. Consolidated text: Dz.U. 2016, poz. 778, with amendments.

[3] Ustawa $z$ dnia 7 lipca 1994 r. o zagospodarowaniu przestrzennym [Act of 7 July 1994 on spatial development]. Consolidated text: Dz.U. 1999, nr 15, poz. 139, with amendments.

[4] Dzienniki Urzędowe Województwa Warszawskiego 1995-1998 [Official Journals of the Warsaw Voivodeship 1995-1998]. Wojewoda Warszawski.

[5] Dzienniki Urzędowe Województwa Mazowieckiego 1999-2016 [Official Journals of the Warsaw Voivodeship 1999-2016]. Wojewoda Mazowiecki.

[6] Zmiana Studium UiKZP Miasta Otwocka [Change of study of preconditions and guidelines of spatial development of the Otwock city]. Uchwała Nr LII/540/2014 Rady Miasta Otwocka z dnia 10.06.2014 r. 
[7] Studium UiKZP Miasta Ząbki [Study of preconditions and guidelines of spatial development of the Ząbki city]. Uchwała Nr IX/48/2011 Rady Miasta Ząbki z dnia 26.04.2011 r.

[8] Studium UiKZP Miasta Marki [Study of preconditions and guidelines of spatial development of the Marki city]. Uchwała Nr XXXI/226/2012 Rady Miasta Marki z dnia 24.10.2012 r.

[9] Zmiana UiKZP Miasta Zielonka [Change of study of preconditions and guidelines of spatial development of the Zielonka city]. Uchwała $\mathrm{Nr}$ XVII/145/08 Rady Miasta Zielonka z dnia 7.02.2008 r.

[10] Zmiana Studium UiKZP Miasta Kobyłka [Change of study of preconditions and guidelines of spatial development of the Kobyłka city]. Uchwała $\mathrm{Nr}$ XXVI/224/16 Rady Miasta Kobyłka z dnia 10.10.2016 r.

[11] Zmiana Studium UiKZP Gminy Wołomin [Change of study of preconditions and guidelines of spatial development of the Wołomin Commune]. Uchwała Nr VIII-95/2011 Rady Miejskiej w Wołominie z dnia 14.10.2011 r.

[12] Rozporzadzenie Ministra Infrastruktury z dnia 26 sierpnia 2003 r. w sprawie wymaganego zakresu projektu miejscowego planu zagospodarowania przestrzennego [Regulation of the Minister of Infrastructure of 26 August 2003 on the required scope of the draft of the local spatial development plan] Dz.U. 2003, nr 164, poz. 1587.

[13] MPZP miasta Józefowa obszaru „Kolonia Błota” [Local spatial development plan of the Józefów city for "Kolonia Błota" area]. Uchwała Nr 426/ IV/2005 Rady Miasta Józefowa z dnia 29.07.2005 r.

[14] MPZP miasta Sulejówek dla kompleksu działek o numerach ewidencyjnych: 56/1, 56/2,56/3, 56/5, 56/6, 57/1,57/2, 57/3, 57/4 w obrębie 63, $\mathrm{w}$ granicach ich własności [Local spatial development plan of the Sulejówek city for a complex of plots with registration numbers: 56/1, 56/2, $56 / 3,56 / 5,56 / 6,57 / 1,57 / 2,57 / 3,57 / 4$ in 63 precinct]. Uchwała Nr 443/L/02 Rady Miasta Sulejówek z dnia 24.05.2002 r.

[15] MPZP części miasta Sulejówka [Local spatial development plan for a part of the Sulejówek city]. Uchwała Nr 150/XXV/08 Rady Miasta Sulejówek $\mathrm{z}$ dnia $26.06 .2008 \mathrm{r}$.

\section{Polityka przestrzenna wybranych gmin podwarszawskich w zakresie obszarów scaleń i wtórnych podziałów nieruchomości}

\footnotetext{
Streszczenie: Celem artykułu była analiza dokumentów planistycznych - studiów uwarunkowań i kierunków zagospodarowania przestrzennego gmin oraz miejscowych planów zagospodarowania przestrzennego - w kontekście regulacji związanych z podziałami na działki budowlane. Analiza została przeprowadzona na przykładzie wybranych gmin podwarszawskich, a ocenie poddano dokumenty planistyczne uchwalone w latach 1995-2016.
} 
Przedmiotowa analiza wykazała, że kwestia scaleń i wtórnych podziałów jest wręcz pomijana w studiach uwarunkowań i kierunków zagospodarowania przestrzennego. Również w planach miejscowych wyjątkowo dokonuje się korekty istniejących parametrów działek. W większości są one adaptowane nawet gdy są nieodpowiednie (np. zbyt wąskie) do zabudowy. W gestii właścicieli pozostawia się sposób podziału nieruchomości, łącznie z wewnętrzną obsługą komunikacyjną. Wprowadzane zasady podziału terenów na działki budowlane mają przeważnie charakter postulatów. Jedynym powszechnie występującym ustaleniem planistycznym jest minimalna powierzchnia działki budowlanej.

Brak regulacji planistycznych lub znaczy stopień ich ogólności w danym zakresie może prowadzić do tworzenia wadliwych struktur przestrzennych, kosztochłonnych w ewentualnym przyszłym procesie poprawy standardów użytkowych. $\mathrm{Na}$ analizowanych obszarach występują nie tylko pojedyncze kwartały zagospodarowane w ten sposób, ale nawet całe rejony, pocięte siatką długich i zbyt wąskich ulic, obsługujących działki trudne do prawidłowego zabudowania.

\section{Słowa}

kluczowe: polityka przestrzenna, scalenia i wtórne podziały nieruchomości 